\title{
Hemacytotoxicity and natural killer lytic index: New parameters to evaluate natural killer cell immunity for clinical use in cancer
}

\author{
HYUNG GUN MAENG ${ }^{1}$, SU JIN LEE ${ }^{1}$, YUN A LEE ${ }^{1}$, HYE JEONG LEE ${ }^{1}$, \\ YOUNG JOO KIM ${ }^{1}$, JONG KYUN LEE ${ }^{1,2}$, JAE CHEOL KIM ${ }^{1,2}$ and JOUNGBUM CHOI ${ }^{1}$ \\ ${ }^{1}$ Immunology Laboratory, Holon Center; ${ }^{2}$ Department of Surgery, Seoul Song \\ Do Colorectal Hospital, Seoul 04597, Republic of Korea
}

Received December 14, 2015; Accepted June 9, 2017

DOI: $10.3892 / \mathrm{ol} .2017 .7365$

\begin{abstract}
Cytotoxicity assays with patient peripheral blood mononuclear cell (PBMC)-derived natural killer (NK) cells are useful in evaluating the innate immunity of patients with cancer. However, the size of the NK cell population in PBMC preparations may have significant effects on the assay outcome. Therefore, the present study examined the effect of NK cell frequency in a cytotoxicity system to investigate NK cell immunity in post-surgical colorectal cancer patients. For this, hemacytotoxicity was assessed using PBMC preparations, and lymphocyte subset populations were analyzed in samples obtained from 47 patients and 45 healthy volunteers. In addition, a new theoretical parameter, the 'NK lytic index', was termed to represent the per-cell cytotoxicity and compensate for the NK cell frequency effect during PBMC preparations. Notably, the patterns of hemacytotoxicity and NK lytic index did not coincide in follow-up studies with consecutive patients following surgical intervention. In addition, it was determined that NK cell NKG2D expression influences NK lytic index, but not hemacytotoxicity. Transforming growth factor (TGF)- $\beta$-bound lymphocytes influenced hemacytotoxicity and NK lytic index. These findings indicate that total cell activity (hemacytotoxicity) is not a sum of per-cell activities (NK lytic indexes), suggesting that clinicians should employ NK lytic index in addition to hemacytotoxicity in order to precisely determine how to enhance NK cell immunity in patients with cancer, either
\end{abstract}

Correspondence to: Dr Joungbum Choi, Immunology Laboratory, Holon Center, Seoul Song Do Colorectal Hospital, 78 Dasan-ro, Jung-gu, Seoul 04597, Republic of Korea

E-mail: jounnn@gmail.com

Abbreviations: AUC, area under the curve; CRC, colorectal cancer; $\mathrm{E} / \mathrm{T}$, effector-to-target cell ratio; FITC, fluorescein isothiocyanate; LI, lytic index; NK, natural killer; PBMC, peripheral blood mononuclear cell; PE, phycoerythrin

Key words: natural killer cells, cell-mediated immunity, colorectal cancer, clinical oncology, clinical laboratory techniques focusing on recovering the number of NK cells or boosting NK cell activity in single cell levels, or both.

\section{Introduction}

Natural killer (NK) cells, which serve critical roles in cancer immunity, are regarded as the first line of defense to eliminate transformed or malignant tumor cells (1). Therefore, multiple clinical laboratories have examined the implications of NK cell-mediated immunity in cancer and demonstrated that NK cells are functionally impaired in the majority of forms of cancer (2-4). Therefore, clinical attempts to boost endogenous NK cell activity, using biological response modifiers or the adoptive transfer of in vitro activated NK cells, have been investigated for the treatment of patients with cancer $(5,6)$. However, a reliable tool to evaluate NK cell activity on a per-cell basis in each patient should be described prior to clinical application in order to design optimal treatment regimens, particularly since the degree of impaired NK cell activity and its etiology differ from patient to patient (7-9).

In vitro cytotoxicity assays have been widely used in clinical laboratories to study NK cell function in patients with cancer. A feature of this assay system is the co-culture of effector cells with their specific target cells over a range of ratios, in which the cytotoxicity of NK cells against their target cells is measured by arithmetic calculation of the number of target cells killed during the given reaction. Purified peripheral NK cells from blood are a favored source of effector cells, but unfractionated peripheral blood mononuclear cells (PBMCs) can also suffice in these analyses. PBMCs are typically employed in research laboratories, owing to the simple preparation procedures in comparison with NK cell-specific isolations $(2,10)$. However, the use of pooled PBMCs prepared by a given number of cells as effector cells has a clear disadvantage: Variations in NK cell frequency in every pool of PBMCs hinders the accurate interpretation of a net- or per-cell cytotoxicity for NK cells, particularly since cytotoxicity, described as the percent (\%) of dead target cells, tends to be strongly influenced by alterations in the NK cell population size within PBMC preparations (11-13).

Considering these factors, PBMCs in cytotoxicity assays should be quantified per $\mathrm{ml}$ of blood to reflect the natural fluctuations in the NK cell population within the bloodstream. 
This may result in an improved understanding in cellular cytotoxicity, since these changes in cell number are examined simultaneously.

The present study presents a novel and simple method of resolving the NK cell frequency effect by measuring NK cell cytotoxicity in patients with cancer and addressing new technical terms, including 'hemacytotoxicity' and 'NK lytic index,' which describe cytotoxicity of an undetermined number of PBMCs per $\mathrm{ml}$ of blood and the arithmetical per-cell activity of NK cells inferred from the hemacytotoxicity measure, respectively. Finally, the present study illustrates a practical way of employing hemacytotoxicity and the NK lytic index to improve understanding of NK cell-mediated immunity in patients with cancer.

\section{Materials and methods}

Subjects. Blood was drawn from 47 patients (26 males and 21 females; age range, 34 76) with colorectal cancer (CRC) and 45 healthy volunteers (23 males and 22 females; age range, 48 82), and immediately collected into heparinized tubes for in vitro cellular functional assays and into potassium-EDTA tubes (Greiner Bio-One, Kremsmünster, Austria) for the enumeration of lymphocyte subsets. Informed written consent with a questionnaire to identify medical history was obtained from all the participants. In case of the patients, blood was collected at least three times: 3-8 days prior to surgery, and then 7 days and 1 month after the surgery. All procedures were performed with the approval of the institutional review board of Seoul Song Do Colorectal Hospital (IRB Number 2014-008).

Cytotoxicity assays. NK cell cytotoxicity against K562 cells was tested following two different PBMC isolation methods as described in our previous work (12). K562 cells (KCLBNo. 10243), a human erythromyeloblastoid leukemia cell line, were obtained from Korean Cell Line Bank (Seoul, Korea) and maintained in RPMI-1640 medium (Welgene, Inc., Gyeongsang, Korea) supplemented with 5\% (v/v) fetal bovine serum (FBS; Gibco; Thermo Fisher Scientific, Inc., Waltham, MA, USA) and 1\% (v/v) penicillin-streptomycin (Gibco; Thermo Fisher Scientific, Inc.) in a humidified incubator (Thermo Fisher Scientific, Inc.) with $5 \% \mathrm{CO}_{2}$ at $37^{\circ} \mathrm{C}$. The cell line was characterized utilizing short tandem repeat profiling. For comparative analysis of two different assays, 'conventional cytotoxicity assays' were performed with three different effector-to-target cell ratios (E/T): $1.25 \times 10^{5}, 2.5 \times 10^{5}$ and $5 \times 10^{5}$ PBMCs against 20,000 K562 cells. Similarly, blood cytotoxicity assays were simultaneously conducted with three different preparations of PBMCs from 250, 500, and 1,000 $\mu \mathrm{l}$ of blood against 20,000 K562 cells. Then, a single E/T ratio of 1:25 was used for conventional cytotoxicity, and PBMCs from $500 \mu \mathrm{l}$ of blood were tested against 2,000 K562 cells for hemacytotoxicity. Percent cytotoxicity was measured by using CytoTox 96 non-Radioactive assay kits (Promega Corporation, Madison, WI, USA) according to the manufacturer's protocol. The result of conventional cytotoxicity assays was defined as 'cytotoxicity' and that of the per-ml blood cytotoxicity assay was marked as 'hemacytotoxicity' to distinguish between the results (Figs. 1A and
B). Percent cytotoxicity was calculated using the following formula:

Cytotoxicity $(\%)=[($ experimental release-effector spontaneous release-target spontaneous release)/(target maximum release-target spontaneous release)]x 100 .

Analysis of blood lymphocyte subsets. Blood was collected in EDTA-coated vacuum containers and the percentages of $\mathrm{CD}^{+} \mathrm{T}$ cells, $\mathrm{CD}^{+}{ }^{+} \mathrm{CD} 4^{+}$helper $\mathrm{T}$ cells, $\mathrm{CD}^{+} \mathrm{CD}^{+}$cytotoxic T cells, NKG2D-positive $\mathrm{CD}^{-}{ }^{-} \mathrm{CD} 56^{+} \mathrm{NK}$ cells, and $\mathrm{CD}^{+} \mathrm{CD}^{2} 6^{+} \mathrm{NKT}$ cells were analyzed in erythrocyte-lysed whole blood by flow cytometry. Briefly, $50 \mu \mathrm{l}$ of blood was aliquoted into $12 \times 75-\mathrm{mm}$ capped polypropylene test tubes and stained blood cells in a dark room for $15 \mathrm{~min}$ at room temperature using the following mouse anti-human monoclonal antibodies (MoAbs) purchased from BD Biosciences (San Jose, CA, USA): Anti-CD3-fluorescein isothiocyanate (FITC; 1:100; cat. no. 555339), anti-CD8-phycoerythrin (PE; 1:100; cat. no. 555635), anti-CD4-PE-Cy5 (1:100; cat. no. 555348), anti-CD56-PE (1:20; cat. no. 555516), and anti-CD314-PE-Cy5 (1:20; cat. no. 562365). Erythrocyte in blood cells were then lysed by adding $450 \mu \mathrm{l}$ of FACS lysing solution (BD Biosciences, Franklin Lakes, NJ) for $15 \mathrm{~min}$ at room temperature, and analyzed using flow cytometry (FACSCalibur; BD Biosciences). Enumeration of lymphocyte subsets was analyzed by double platform method by calculating absolute counts from the lymphocyte differentials using an automatic hematology analyzer (Sysmex Corporation, Kobe, Japan). Data were analyzed using CellQuest ${ }^{\mathrm{TM}}$ Pro software version 6.0 (BD Biosciences).

Analysis of surface-bound transforming growth factor (TGF)- $\beta$ on lymphocyte subsets. Surface-bound TGF- $\beta$ expression on lymphocyte subsets was analyzed using flow cytometry with a panel of MoAbs against FITC/PE/Peridinin chlorophyll protein complex combinations of CD4 (1:100; cat. no. 555346)/CD25 (1:20; cat. no. 555432)/TGF- $\beta 1$ (1:20; cat.no.FAB2463C) andCD19(1:100; cat.no.555412)/CD25/TGF$\beta 1$ for the analysis of $\mathrm{CD} 4{ }^{+} \mathrm{CD} 25^{+}$regulatory $\mathrm{T}$ cells and $\mathrm{CD} 19^{+}$regulatory $\mathrm{B}$ cells, respectively. Anti-TGF- $\beta 1$ antibody was purchased from R\&D Systems, Inc. (Minneapolis, MN, USA) and the remaining antibodies were purchased from BD Biosciences. PBMCs $(10 \mu \mathrm{l})$ derived from $100 \mu \mathrm{l}$ blood were incubated at room temperature with human FC block (1:10; cat. no. 564220; BD Biosciences) for $30 \mathrm{~min}$, labeled with each panel of antibodies and $40 \mu \mathrm{l}$ PBS, incubated for $30 \mathrm{~min}$ at room temperature in the dark, washed in PBS, centrifuged at $440 \mathrm{xg}$ for $5 \mathrm{~min}$ at room temperature, and then resuspended in $200 \mu \mathrm{l}$ PBS. Flow cytometry was performed using a FACSCalibur ${ }^{\mathrm{TM}}$ flow cytometer (BD Biosciences) and CellQuest ${ }^{\mathrm{TM}}$ Pro software version 6.0 (BD Biosciences).

Statistical analysis. Pearson's and Spearman's correlation tests and the Student's t-test were used for statistical tests, and all analyses were carried out using the SPSS statistical package program, version 18 (SPSS, Inc., Chicago, IL, USA), except for determination of sensitivity, specificity, positive predictive value (PPV), negative predictive value (NPV), and area under the curve (AUC) obtained by Receiver operating characteristic analysis for identifying patients with CRC. For 
Table I. Clinical characteristics of patients with colorectal cancer and healthy controls.

\begin{tabular}{|c|c|c|}
\hline Characteristics & $\begin{array}{l}\text { Patient } \\
\text { group } \\
(\mathrm{n}=47)\end{array}$ & $\begin{array}{l}\text { Healthy } \\
\text { control } \\
\text { group } \\
(n=45)\end{array}$ \\
\hline \multicolumn{3}{|l|}{ Gender } \\
\hline Male & 26 & 23 \\
\hline Female & 21 & 22 \\
\hline Age $(y r)$, mean \pm SD & $61 \pm 11$ & $59 \pm 9$ \\
\hline \multicolumn{3}{|l|}{ T stage } \\
\hline $\mathrm{T} 1$ & 1 & \\
\hline $\mathrm{T} 2$ & 4 & \\
\hline $\mathrm{T} 3$ & 35 & \\
\hline $\mathrm{T} 4$ & 7 & \\
\hline \multicolumn{3}{|l|}{ Nodal status } \\
\hline N0 & 13 & \\
\hline N1 & 17 & \\
\hline $\mathrm{N} 2$ & 17 & \\
\hline \multicolumn{3}{|l|}{ Distant metastasis } \\
\hline M0 & 44 & \\
\hline M1 & 3 & \\
\hline \multicolumn{3}{|l|}{ Stage } \\
\hline $\mathrm{I}$ & 0 & \\
\hline II & 13 & \\
\hline III & 30 & \\
\hline IV & 4 & \\
\hline
\end{tabular}

this, DeLong's test was used and calculations were performed using MedCalc software, version 9.5.2 (MedCalc Software bvba, Ostend, Belgium). $\mathrm{P}<0.05$ was considered to indicate a statistically significant difference.

\section{Results}

Clinical characteristics of the study population. A total of 47 patients (26 males and 21 females) with CRC and 45 healthy volunteers ( 23 males and 22 females) were classified by gender and age. There were no age differences between patients and healthy groups $(61 \pm 11$ years vs. $59 \pm 9$ years, $\mathrm{P}=0.538)$. The tumor-node-metastasis (TNM) staging system was used for further classification of the patients (Table I).

NK cell frequency effect on percent cytotoxicity. It was anticipated that NK cell frequency in the pool of PBMCs in the cytotoxicity assay system would affect the percent cytotoxicity. Therefore the effect of the frequency of NK cells and other lymphocyte subsets on percent cytotoxicity was investigated. To begin with, conventional cytotoxicity and hemacytotoxicity were assessed in two different methods of preparing PBMCs from 20 healthy volunteers. The mean concentration of PBMCs was $9.36 \pm 3.04 \times 10^{5}$ cells $/ \mathrm{ml}$, and the percent cytotoxicity for the three different ratios in both methods demonstrated a linear correlation with the proportion of PBMCs ( $r=0.994$ for conventional cytotoxicity and 0.996 for hemacytotoxicity, $\mathrm{P}<0.001$; Fig. 1A and B). Therefore, a 1:25 ratio $\left(20,000\right.$ K562 cells: $5 \times 10^{5}$ PBMCs) for conventional cytotoxicity, and the PBMCs in $500 \mu \mathrm{l}$ of blood against 20,000 K562 cells for hemacytotoxicity, were selected from the three different ratios. Cytotoxicity and hemacytotoxicity were correlated with the absolute number of NK cells in the pooled PBMCs $(r=0.680$ and $r=0.671 ; P<0.001$, in both cases; Fig. 1C and D), but not with the other cell types in the lymphocytes (data not shown). Two different percent cytotoxicities were positively correlated $(\mathrm{r}=0.847, \mathrm{P}<0.001)$ where if the percentage of conventional cytotoxicity were increase, the percentage of hematocytotoxicity also rise as demonstrated in Fig. 1E; however, the mean ranks of 20 healthy volunteers were significantly different $(\mathrm{P}=0.024$; Fig. $1 \mathrm{~F})$. These observations indicated that $\mathrm{NK}$ cell frequency influences percent cytotoxicity regardless of PBMC preparation method and should be properly adjusted to accurately determine the cytotoxicity at a single-cell level in the cytotoxicity assay system.

Compensation of NK cell frequency effect on percent cytotoxicity. To compensate for the effect of NK cell frequency on percent cytotoxicity, a novel method was developed for determining the single cell activity of NK cells. Preparation of PBMCs per ml of blood enabled the counting of the total number of NK cells in such a way that it would be possible to calculate the dead target cell counts per one single NK cell in the reaction. However, it was technically difficult to determine NK cell numbers in the conventional cytotoxicity assay system from a given number of PBMCs. Therefore, by using hemacytotoxicity and absolute numbers of NK cells in a given volume of blood, a new parameter, NK lytic index, was devised to assess the inferential single cell activity of NK cells. The formula for NK lytic index is as follows: NK lytic index $(\mathrm{LI})=$ dead target cell counts/NK cell counts $\mathrm{x} 1,000$.

Therefore, one NK lytic index (LI) can be defined as an arithmetical unit of single NK cell activity against target cells. The lytic index for one of the healthy volunteers was calculated in the following manner: $2 \times 10^{4} \mathrm{~K} 562$ cells were co-cultured with undetermined numbers of PBMCs derived from $500 \mu \mathrm{l}$ of whole blood and the consequent hemacytotoxicity was $20 \%$. Then, the number of lysed K562 cells in the reaction was determined to be $4 \times 10^{3}$ cells by calculation of $\left(2 \times 10^{4}\right.$ initial K562 cells $) \times\left(0.2_{\text {percent hemacytotoxicity }}\right)$. The absolute number of NK cells was 500 cells/ $\mu \mathrm{l}$ and the total number of NK cells in the reaction was $2.5 \times 10^{5}$ cells by calculation of $\left(500\right.$ cells $/ \mu 1_{\text {absolute }}$ number of NK cells $) \times\left(500 \mu 1_{\text {initial blood volume }}\right)$ in the pool of PBMCs from $500 \mu \mathrm{l}$ of blood. Thus, NK lytic index was 16 LI by division of $\left(4 \times 10^{3}\right.$ dead target cells $)$ by $\left(2.5 \times 10^{5}\right.$ total NK cells in $500 \mu$ l blood $) \times 1,000$. With this process, the NK lytic index of 20 healthy donors was calculated as depicted in Table II.

Inconsistent patterns of hemacytotoxicity and NK lytic index. Next, it was investigated whether the patterns of NK lytic index (single-cell activity) were consistent with those of hemacytotoxicity (total-cell activity). To compare these two parameters, the effect of surgery on hemacytotoxicity and NK lytic index was investigated in 47 patients with CRC. The hemacytotoxicity of preoperative (pre-op) patients was reduced significantly 7 days following surgery $(11.01 \pm 5.87 \%$ 
A

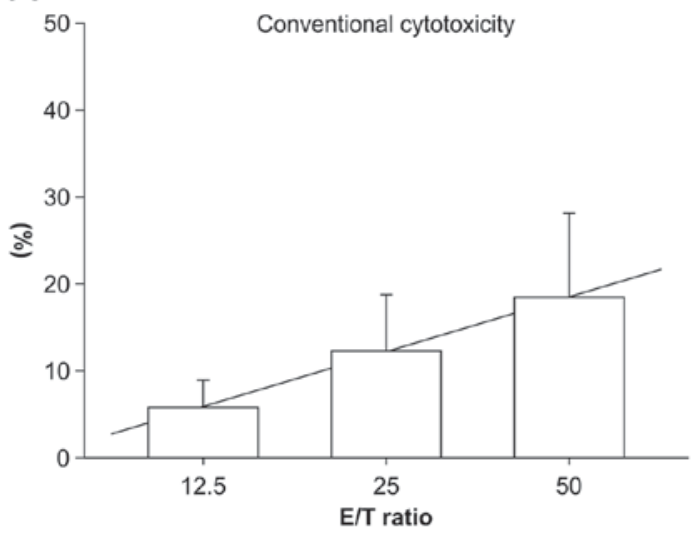

C

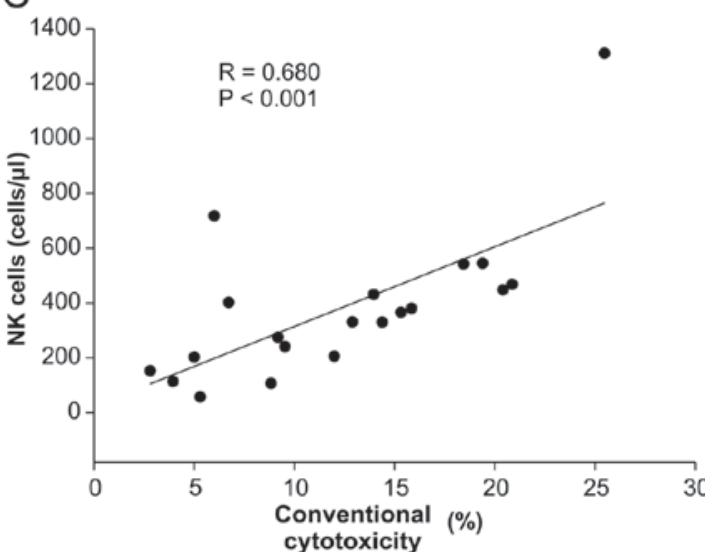

E

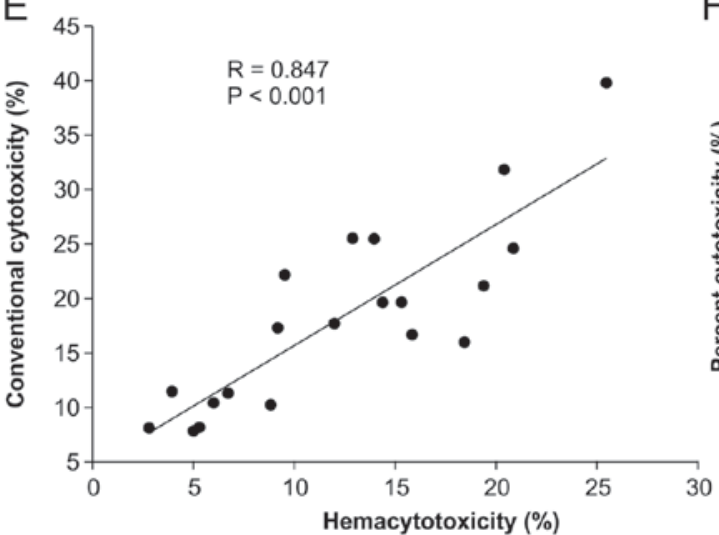

B

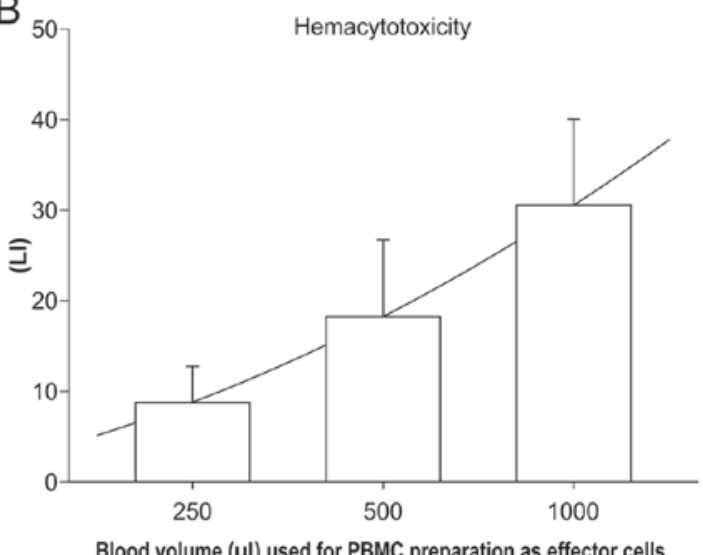

Blood volume $(\mu \mathrm{l})$ used for PBMC preparation as effector cells

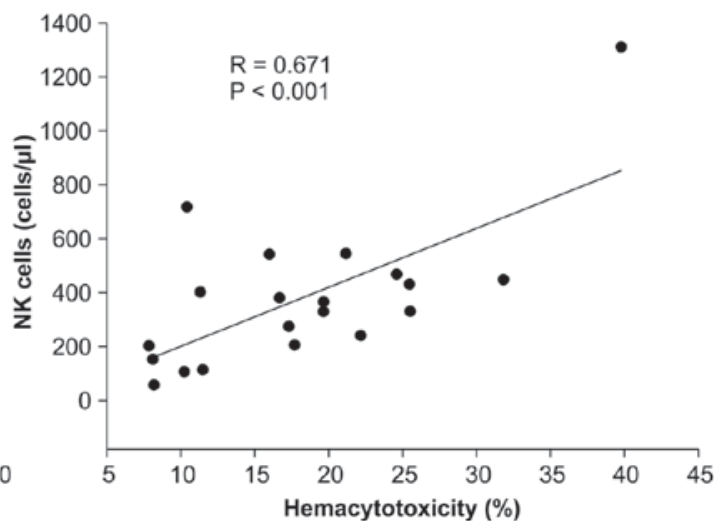

F

$\mathrm{F}$

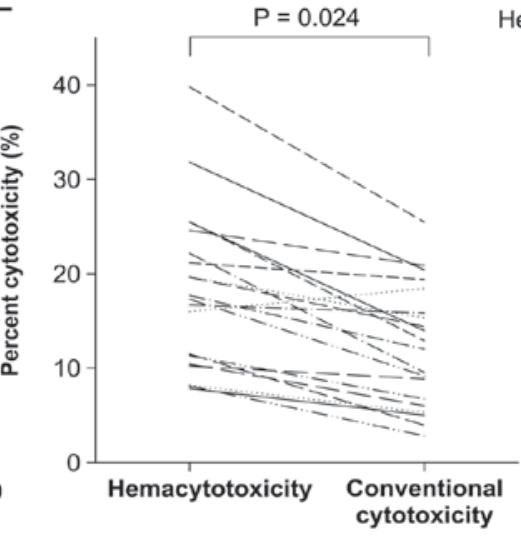

Healthy volunteers

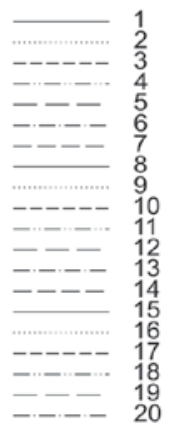

Figure 1. Influence of NK cell number on percent cytotoxicity. (A and B) Cytotoxicity assay of healthy volunteers (n=20) was performed simultaneously in PBMCs prepared by two different methods. Each percent cytotoxicity (\%) was described as hemacytotoxicity and conventional cytotoxicity. (C and D) Pearson's Correlation test was performed between absolute numbers of NK cells and percent cytotoxicity. NK cell numbers were calculated by a double-platform method by using a flow cytometer and an automatic hematology analyzer. (E) Correlation between hemacytotoxicity and conventional cytotoxicity was analyzed by Pearson's correlation test. (F) Mean ranks of two different percent cytotoxicities were analyzed using the Wilcoxon signed-rank test. NK, natural killer; PBMC, peripheral blood mononuclear cell.

vs. $8.91 \pm 4.57 \%, \mathrm{P}=0.0048)$, but almost recovered 30 days later compared with pre-op counterparts $(8.91 \pm 4.51 \%$ vs. $12.68 \pm 6.14 \%, \mathrm{P}<0.001$ ) (Fig. 2A). On the contrary, the NK lytic index in pre-op state was significantly increased 7 days following surgery (12.02 $\pm 8.19 \mathrm{LI}$ vs. $15.54 \pm 9.51 \mathrm{LI}, \mathrm{P}=0.043)$ and decreased again 30 days following surgery $(15.54 \pm 9.51$ LI vs. 11.16 $\pm 4.41 \mathrm{LI}, \mathrm{P}<0.001$ ) (Fig. 2B). NK cell number in pre-op state was significantly decreased following surgery $(418 \pm 232$ cells $/ \mu 1$ vs. $267 \pm 125$ cells $/ \mu 1, \mathrm{P}<0.05)$; however, that was restored 30 days following surgery $(267 \pm 125$ cells $/ \mu 1 \mathrm{vs}$. 474 \pm 194 cells $/ \mu 1, \mathrm{P}<0.05$ ) (Fig. 2 C).
Different impact of NKG2D and TGF- $\beta$ on hemacytotoxicity and NK lytic index. On account of the different impacts of surgical treatment on hemacytotoxicity and NK lytic index, it was examined whether expression levels of NKG2D on NK cells and surface-bound TGF- $\beta$ on $\mathrm{CD} 4^{+} \mathrm{CD} 25^{+}$regulatory $\mathrm{T}$ cells or $\mathrm{CD} 19^{+}$regulatory $\mathrm{B}$ cells affected hemacytotoxicity and $\mathrm{NK}$ lytic index differently. NKG2D expression on CD $3{ }^{-} \mathrm{CD}^{-} 6^{+} \mathrm{NK}$ cells was positively correlated with $\mathrm{NK}$ lytic index $(\mathrm{r}=0.424, \mathrm{P}=0.006)$ but not with hemacytotoxicity $(\mathrm{r}=0.115, \mathrm{P}=0.473)$ (Fig. 3A and $\mathrm{B})$. However, surface-bound TGF- $\beta$ on regulatory T cells and regulatory B cells did not exhibit any correlation with hemacytotoxicity 
Table II. Data on the NK lytic index of 20 healthy volunteers, used to adjust NK cell frequency in PBMC preparation.

\begin{tabular}{|c|c|c|c|c|c|c|}
\hline Number & Gender & Age & NK cells ${ }^{\mathrm{a}}$ & Hemacytotoxicity $^{\mathrm{b}}$ & $\begin{array}{l}\text { Conventional } \\
\text { cytotoxicity }^{\mathrm{b}}\end{array}$ & NK lytic index ${ }^{c}$ \\
\hline 1 & $\mathrm{~F}$ & 63 & 448 & 31.82 & 20.40 & 28.41 \\
\hline 2 & M & 58 & 366 & 19.65 & 15.32 & 21.48 \\
\hline 3 & M & 35 & 1,311 & 39.78 & 25.47 & 12.14 \\
\hline 4 & $\mathrm{~F}$ & 43 & 275 & 17.30 & 9.18 & 25.16 \\
\hline 5 & M & 68 & 718 & 10.42 & 6.00 & 5.81 \\
\hline 6 & $\mathrm{M}$ & 60 & 206 & 17.69 & 11.99 & 34.35 \\
\hline 7 & $\mathrm{~F}$ & 56 & 114 & 11.48 & 3.94 & 40.28 \\
\hline 8 & M & 44 & 431 & 25.46 & 13.96 & 23.63 \\
\hline 9 & $\mathrm{~F}$ & 51 & 58 & 8.18 & 5.30 & 56.41 \\
\hline 10 & M & 53 & 545 & 21.16 & 19.39 & 15.53 \\
\hline 11 & $\mathrm{~F}$ & 61 & 153 & 8.11 & 2.81 & 21.20 \\
\hline 12 & M & 66 & 468 & 24.59 & 20.86 & 21.02 \\
\hline 13 & $\mathrm{~F}$ & 51 & 381 & 16.68 & 15.84 & 17.51 \\
\hline 14 & $\mathrm{M}$ & 53 & 330 & 19.64 & 14.38 & 23.81 \\
\hline 15 & $\mathrm{~F}$ & 50 & 203 & 7.84 & 5.01 & 15.45 \\
\hline 16 & $\mathrm{M}$ & 53 & 542 & 15.99 & 18.43 & 11.80 \\
\hline 17 & $\mathrm{~F}$ & 56 & 331 & 25.51 & 12.89 & 30.83 \\
\hline 18 & $\mathrm{~F}$ & 24 & 402 & 11.32 & 6.72 & 11.26 \\
\hline 19 & $\mathrm{M}$ & 67 & 107 & 10.23 & 8.83 & 38.24 \\
\hline 20 & $\mathrm{~F}$ & 59 & 241 & 22.17 & 9.53 & 36.80 \\
\hline
\end{tabular}

${ }^{\mathrm{a}} \mathrm{cell} / \mathrm{s} / \mu 1,{ }^{\mathrm{b}} \%$; ${ }^{\mathrm{C} L I}$. NK, natural killer.
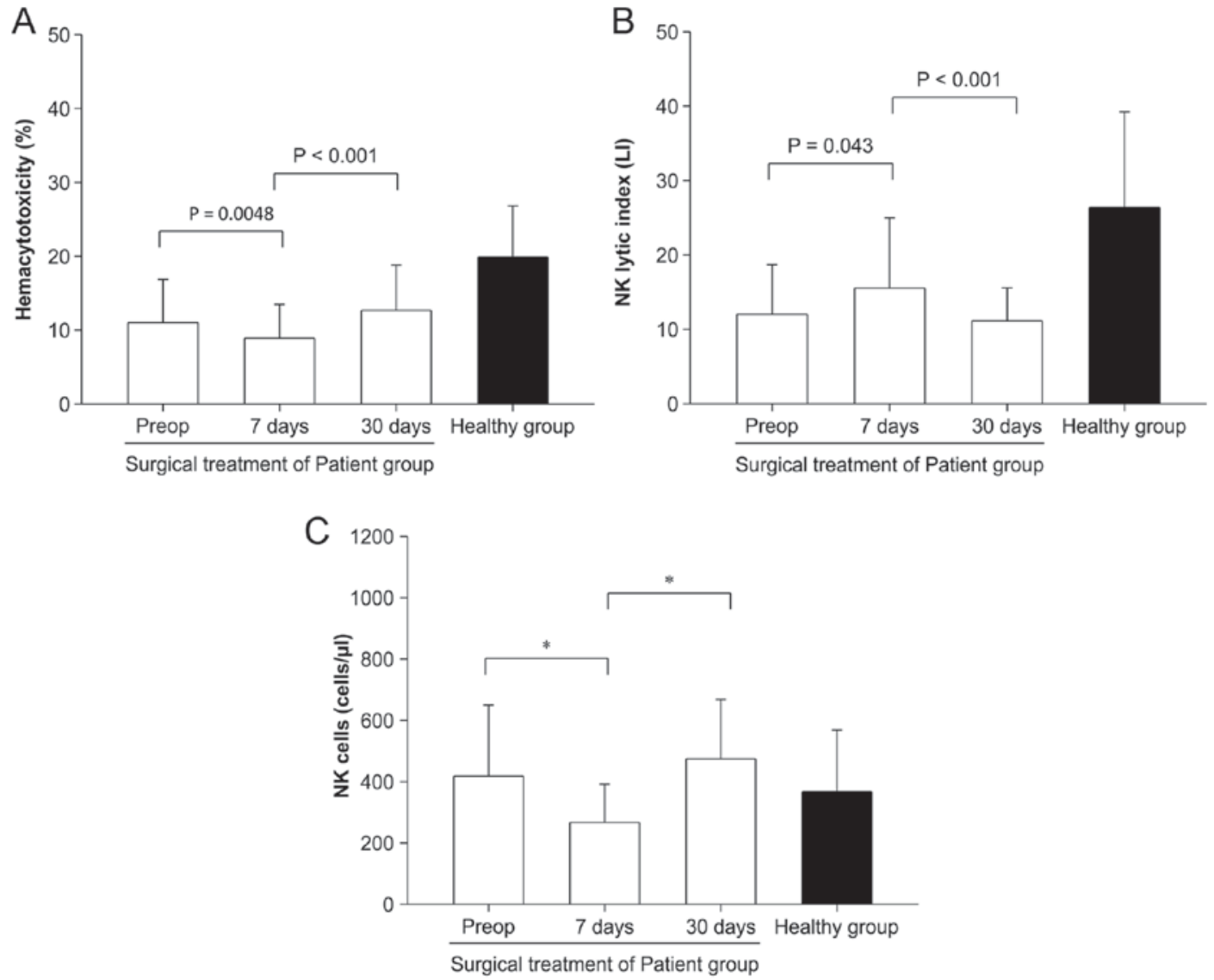

Figure 2. Effect of surgical treatment on (A) hemacytotoxicity, (B) NK lytic index and (C) NK cell numbers. According to time following surgery, consecutive analyses of hemacytotoxicity, NK lytic index, and absolute numbers of NK cells in patients $(\mathrm{n}=47)$, compared to those in healthy volunteers ( $\mathrm{n}=45)$ were performed. Student's t-test was performed for statistical analysis. ${ }^{*} \mathrm{P}<0.05$. NK, natural killer. 
Table III. Sensitivity, specificity, PPV, and NPV for hemacytotoxicity and NK lytic index.

\begin{tabular}{lccccc}
\hline Variable & $\begin{array}{c}\text { Sensitivity } \\
(95 \% \mathrm{CI})\end{array}$ & $\begin{array}{c}\text { Specificity } \\
(95 \% \mathrm{CI})\end{array}$ & PPV $(95 \% \mathrm{CI})$ & NPV (95\% CI) & AUC (95\% CI) \\
\hline $\begin{array}{l}\text { Hemacytotoxicity (\%) } \\
>13.92\end{array}$ & $84.44(70.5-93.5)$ & $70.21(55.1-82.7)$ & $73.1(59.0-84.4)$ & $82.5(67.2-92.7)$ & $0.831(0.738-0.901)$ \\
$\quad$ & & & & & \\
$\quad \begin{array}{l}\text { NK lytic index (LI) } \\
>14.2\end{array}$ & $84.44(70.5-93.5)$ & $65.96(50.7-79.1)$ & $70.4(56.4-82.0)$ & $81.6(65.7-92.3)$ & \\
$>16.69$ & $71.11(55.7-83.6)$ & $74.47(59.7-86.1)$ & $72.7(57.2-85.0)$ & $72.9(58.2-84.7)$ & $0.843(0.752-0.911)$ \\
$>18.17$ & $62.22(46.5-76.2)$ & $80.85(66.7-90.9)$ & $75.7(58.8-88.2)$ & $69.1(55.2-80.9)$ &
\end{tabular}

PPV, positive predictive value; NPV, negative predictive value; AUC, area under the curve; NK, natural killer.
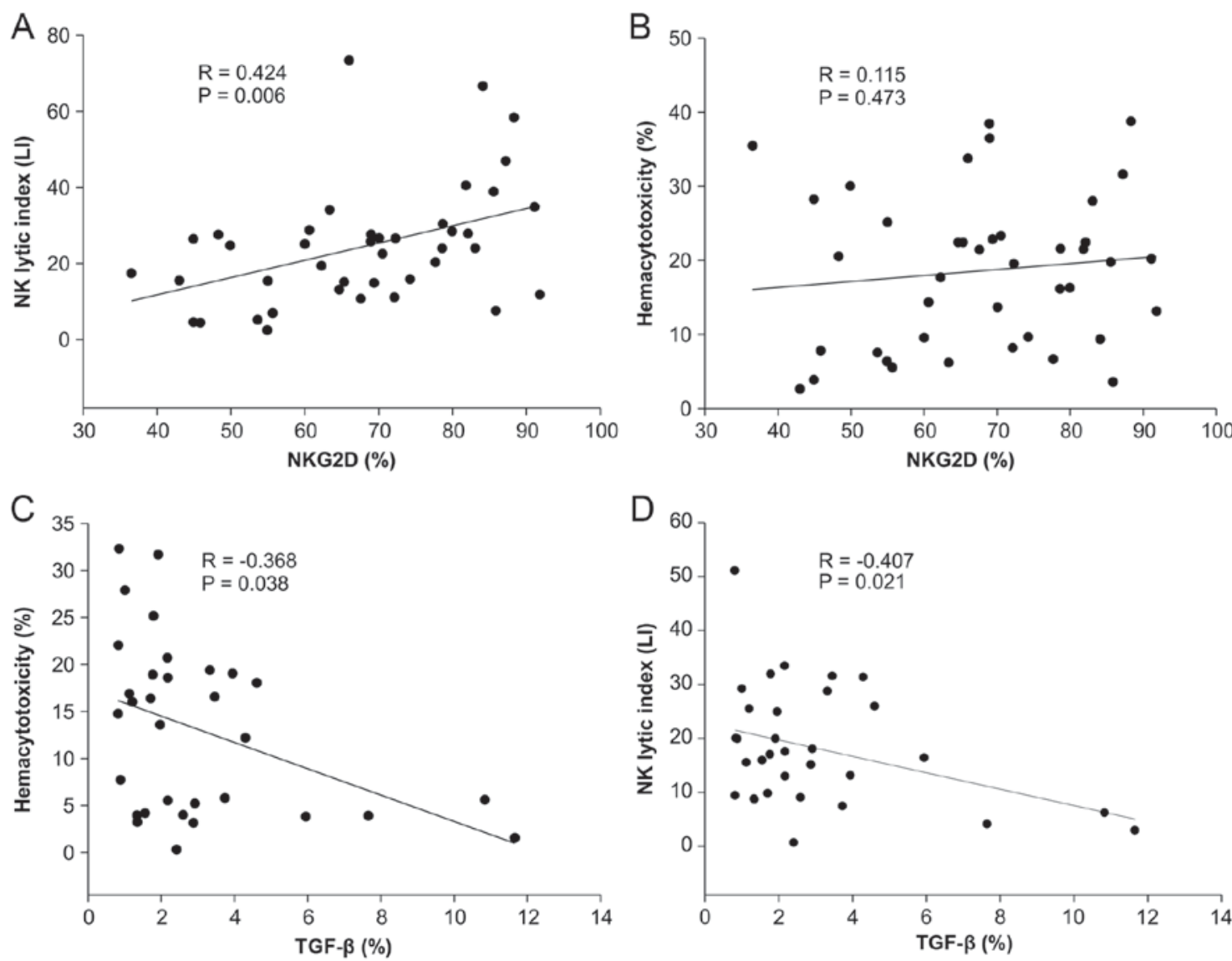

Figure 3. Effect of lymphocyte cell surface NKG2D and TGF- $\beta$ expression on hemacytotoxicity and NK lytic index. (A and B) Cell surface NKG2D expression on NK cells was analyzed and correlative significance with hemacytotoxicity and NK lytic index was investigated. (C and D) Surface-bound TGF- $\beta$ on total lymphocytes was analyzed and a correlation test was performed to determine the correlation with hemacytotoxicity and NK lytic index. Data were obtained from 18 healthy volunteers and 23 patients for NKG2D analysis, and from 18 healthy volunteers and 14 patients for surface-bound TGF- $\beta$ analysis. All patients consisted of those who were subjected to chemotherapy following surgery. Spearman's correlation test was used for data analysis. NK, natural killer; TGF- $\beta$, transforming growth factor- $\beta$.

and NK lytic index (data not shown). The total TGF- $\beta$ expressing cell population examined by light scatter gating using forward vs. side scatter was negatively correlated with hemacytotoxicity and NK lytic index $(r=-0.368$ and $r=-0.407$, respectively; $\mathrm{P}<0.05$ in both cases) (Fig. 3C and D).

Sensitivity, specificity, and predictive values of hemacytotoxicity and NK lytic index in preoperative patients with colorectal cancer. Hemacytotoxicity and NK lytic index from 47 preoperative patients and healthy volunteers were further analyzed for comparison. In hemacytotoxicity, the optimal cutoff value was 13.92 and value $>13.92 \%$ had best sensitivity, specificity, positive predictive value (PPV), and negative predictive value (NPV). For the NK lytic index, as the cutoff value increased from 14.2 LI to $18.17 \mathrm{LI}$, the sensitivity and PPV value decreased but the specificity and NPV value 


\begin{tabular}{|c|c|c|c|c|c|c|}
\hline \multirow{2}{*}{ Test } & \multirow{2}{*}{ Surgery } & \multirow{2}{*}{ Date of test } & \multicolumn{2}{|c|}{ NK cells } & \multirow{2}{*}{ Hemacytotoxicity } & \multirow{2}{*}{ NK lytic index } \\
\hline & & & $(\%)$ & (cells/ $/ \mathrm{l})$ & & \\
\hline 1 & Preop & 31-May & 30.15 & 933 & 17.35 & 7.44 \\
\hline 2 & Preop & 3-Jun & 26.56 & 546 & 16.08 & 11.79 \\
\hline 3 & Postop & 12-Jun & 39.25 & 986 & 25.85 & 10.49 \\
\hline 4 & Postop & 12-Jul & 42.94 & 1537 & 46.02 & 11.97 \\
\hline 5 & Postop & 6-Sep & 43.38 & 1793 & 46.54 & 10.38 \\
\hline
\end{tabular}
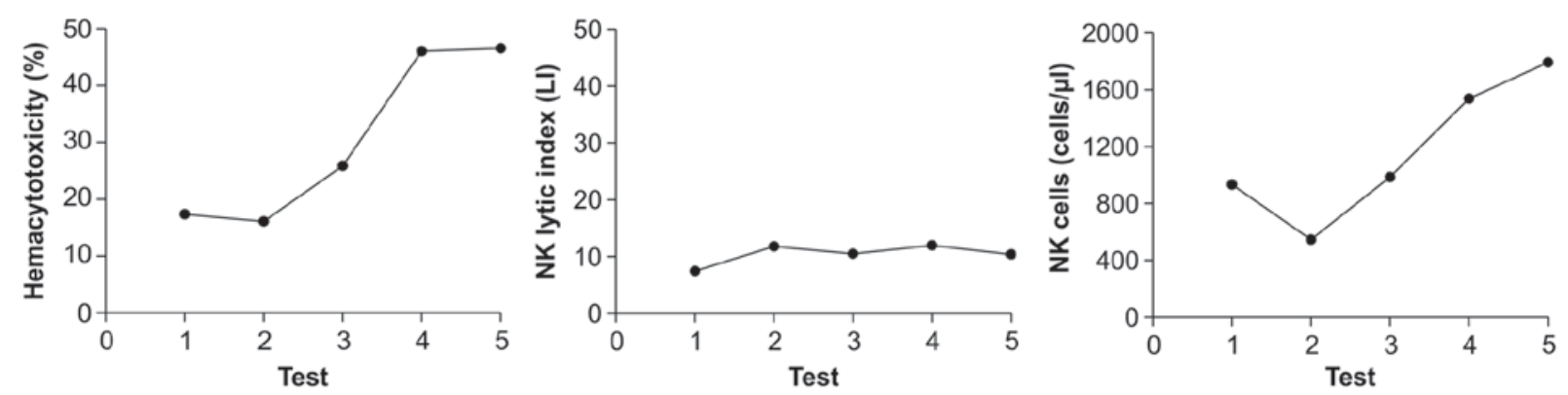

Figure 4. Consecutive analysis for hemacytotoxicity, NK lytic index, and NK cell numbers of one patient to exemplify the way of employing all three parameters simultaneously in order to properly evaluate NK cell activity. NK, natural killer.

increased. Receiver operating characteristic (ROC) curve analysis of hemacytotoxicity and NK lytic index irrespective of cutoff value resulted in 0.831 and $0.843(\mathrm{P}=0.799)$, respectively (Table III).

\section{Discussion}

Despite many advantages, predicting the in vivo states of biological systems by extrapolating in vitro experimental results is challenging (14). The in vitro NK cell cytotoxicity assay using PBMCs is advantageous but also challenging; many researchers and clinicians have employed this useful technique for decades to understand the role of NK cells in various immune-related human diseases (15-17). The introduction of lymphokine-activated killer cells by Rosenberg and colleagues in 1982 (18), encouraged more oncologists to perform this in vitro assay, which has become a gold standard for screening and diagnostic testing tools assessing cancer immunity. Thus, the role of NK cells had been extensively studied by using cytotoxicity assays in terms of implication or correlation of NK cells on critical matters associated with cancer development or treatment, including incidence and prognosis $(13,19,20)$, stage and metastasis $(21,22)$, and surgery and chemotherapy (23-27).

Cytotoxicity assays are often challenging owing to their limitations when used as a general diagnostic tool of cancer immunity in clinical settings. For instance, certain scientists have argued that NK cell cytotoxicity described in percent specific lysis of target cells is not suitable for comparative study even though such comparisons were made at the same $\mathrm{E} / \mathrm{T}$ ratio in a previous study (28). Therefore, the new conceptual parameter, lytic unit, was devised and introduced as an alternative for using percent cytotoxicity (29). A lytic unit can be defined as the number of effector cells necessary to cause lysis of a specified percentage of its target cells (30). However, certain researchers have raised another objection to using the lytic unit in comparing the results of cytotoxicity in patients because the lytic unit inferred from establishing a model of the dose-response curve data may lead to inaccurate estimation (28-30).

However, a fundamental limitation for the general application of the cytotoxicity assay in clinical settings may be the low significance of the results in predicting the pathophysiological states of patients with cancer in terms of cancer immunity; this lack of significance may primarily result from a lack of knowledge of the effect of NK cell frequency on percent cytotoxicity. In particular, the lytic unit does not address the matter of NK cell frequency in the assay system; rather, it should be regarded as a reasonable proxy for the percent lysis generated at various $\mathrm{E} / \mathrm{T}$ ratios. In contrast, an agarose gel or poly-L-lysine hydrobromide polymer-based cell cytotoxicity assay system, in which effector cell/target cell conjugates are made and then the degree of effector cells bound to target cells is measured as a percentage to determine NK cell activity, may resolve the NK cell frequency effect $(31,32)$. This method deals with single-cell activity conceptually equivalent to the lytic index. In fact, this type of assay system has been widely used and published as a 'single-cell cytotoxicity assay.' However, this single-cell cytotoxicity assay should be performed separately from conventional cytotoxicity assays, and the resulting requirement for dual assays may be time-consuming and cumbersome.

In this context, by demonstrating that NK cell frequency significantly influences the results of the percent cytotoxicity in evaluating NK cell activity of patients with cancer, hemacytotoxicity generated from the preparation of PBMCs per ml of blood should be used in place of the conventional cytotoxicity assays, as NK cell frequency effect can be compensated for by adoption of the NK lytic index which simply indicates a net per-cell cytotoxicity. However, NK lytic index would not be the same as a per-cell activity of NK cells resulting from the system, in which isolated pure NK cells are used as effector cells against its target cells; alternatively, it could imply an actual in vivo per-cell activity of NK cells in the bloodstream 
in which NK cells cross-talk with diverse immune cells like dendritic cells, helper $\mathrm{T}$ cells, regulatory $\mathrm{T}$ cells, and NKT cells, and these reciprocal interactions affect NK cell activity (33-35).

On formulating the NK lytic index, the present study identified that the order of rank between a paired hemacytotoxicity and NK lytic index does not correspond as described in Table II. This observation raised the question of whether the total cell activity represented by hemacytotoxicity would be equal to the sum of single cell activities described as NK lytic indexes. To investigate this matter, the surgical effect on the hemacytotoxicity and NK lytic index was investigated with an idea that a number of previous studies demonstrate that surgical stress induces impaired NK cell activity in the early period following surgery $(25,36,37)$. In the present study, hemacytotoxicity decreased at 7 days following surgery but recovered from surgical stress within 30 days; however, NK lytic index increased in 7 days following surgery and decreased again 30 days following surgery. In addition, the redistribution of NK cells corresponded to the changing pattern of hemacytotoxicity. This observation does not agree with those of previous reports indicating that impaired NK cell cytotoxicity is mainly caused by direct toxic effects on NK cells $(24,26)$. Instead, the present study revealed that impaired NK cell activity is primarily due to NK cell redistribution caused by surgical stress, and impaired NK cell total activity may be compensated for by increasing single cell activity by means of immune homeostatic regulation; e.g., the phenomenon that decreasing the number of cytotoxic $\mathrm{T}$ cells may be compensated for by increasing the number of NK cells with ageing (38). Therefore, the results from the present study imply that total NK cell activity is tightly regulated by redistribution of NK cell number and single cell activity.

Similarly, results of further analysis suggested that all three parameters, namely total NK cell activity, NK cell number and single cell activity, should be examined in parallel. Reduced NKG2D expression in NK cells in the majority of patients with cancer has been reported in a number of studies (39-41), and modulation of NKG2D is regarded as a promising therapeutic approach (42). In the present study, NKG2D expression on NK cells correlated with NK lytic index but not with hemacytotoxicity. This observation suggests that decreased NKG2D expression leads to decreased per-cell activity and total cell activity may not be affected by decreased NKG2D expression, because increasing NK cell numbers may overcome decreased per-cell activity. Likewise, TGF- $\beta 1$ is a critical molecule for regulating NK cell activity and induces impaired NK cell activity by the downregulation of NKG2D expression (43-46). The observation from the present study that surface-bound TGF- $\beta 1$ on lymphocytes inversely correlates with hemacytotoxicity and NK lytic index indicates that suppression of TGF- $\beta 1$ signaling may be a critical checkpoint in recovering impaired NK cell function compared with direct modulation of NKG2D expression.

Therefore, parallel analysis of hemacytotoxicity and NK lytic index can be beneficial in evaluating NK cell immunity in patients with cancer as a representative case chosen from among 47 patients (Fig. 4). The patient appeared to be improving in terms of NK cell activity during the study period. However, the seemingly increased hemacytotoxicity is induced by increasing the NK cell number. Therefore, it could not be concluded that the NK cell activity of the patient is improving following surgery because the low NK lytic index of the patient remained unchanged. For this reason, a treatment for increasing single cell activity of NK cells might be first considered in this patient.

There are certain limitations in the system considering hemacytotoxicity and NK lytic index. One is a technical defect in that the absolute counts of NK cells were analyzed in a double-platform method of flow cytometry by using lymphocyte differentials resulting from a hematology analyzer. Regarding immunophenotyping of blood immune cells, a current gold standard is the single platform method (47-49). For this reason, using NK cell counts determined by the above-mentioned method may lower the accuracy of calculating the NK lytic index. The other limitation is the matter of general standardization for clinical application. Since hemacytotoxicity and the NK lytic index also depend on the selected E/T ratio, comparing the results of patients obtained at different E/T ratios would not be appropriate; however, this problem could potentially be circumvented by technical standardization to control for inter- and intra-assay variation.

In conclusion, the present study demonstrated that the NK cell frequency effect on the NK cell cytotoxicity assay using PBMC preparations should be resolved to obtain precise results by employing the NK lytic index. The results indicated that total cell activity is not always a sum of single cell activities, and that surgical treatment exerts different effects on total cell activity (hemacytotoxicity) and single cell activity (NK lytic index). The present study suggests that the three parameters, hemacytotoxicity, NK lytic index, and NK cell number, should be thoroughly assessed to evaluate NK cell immunity in patients with cancer.

\section{Acknowledgements}

The present study was supported and funded (grant no. SD2014008) by Seoul Song Do Colorectal Hospital (Seoul, Republic of Korea).

\section{References}

1. Smyth MJ, Hayakawa Y, Takeda K and Yagita H: New aspects of natural-killer-cell surveillance and therapy of cancer. Nat Rev Cancer 2: 850-861, 2002.

2. Levy EM, Roberti MP and Mordoh J: Natural killer cells in human cancer: From biological functions to clinical applications. J Biomed Biotechnol 2011: 676198, 2011.

3. Coca S, Perez-Piqueras J, Martinez D, Colmenarejo A, Saez MA Vallejo C, Martos JA and Moreno M: The prognostic significance of intratumoral natural killer cells in patients with colorectal carcinoma. Cancer 79: 2320-2328, 1997.

4. Ishigami S, Natsugoe S, Tokuda K, Nakajo A, Che X, Iwashige H, Aridome K, Hokita S and Aikou T: Prognostic value of intratumoral natural killer cells in gastric carcinoma. Cancer 88: 577-583, 2000.

5. Cheng M, Chen Y, Xiao W, Sun R and Tian Z: NK cell-based immunotherapy for malignant diseases. Cell Mol Immunol 10: 230-252, 2013

6. Albertsson PA, Basse PH, Hokland M, Goldfarb RH, Nagelkerke JF, Nannmark U and Kuppen PJ: NK cells and the tumour microenvironment: Implications for NK-cell function and anti-tumour activity. Trends Immunol 24: 603-609, 2003.

7. Balch CM, Tilden AB, Dougherty PA and Cloud GA: Depressed levels of granular lymphocytes with natural killer (NK) cell function in 247 cancer patients. Ann Surg 198: 192-199, 1983. 
8. Levy S, Herberman R, Lippman M and d'Angelo T: Correlation of stress factors with sustained depression of natural killer cell activity and predicted prognosis in patients with breast cancer. J Clin Oncol 5: 348-353, 1987.

9. Schantz SP, Shillitoe EJ, Brown B and Campbell B: Natural killer cell activity and head and neck cancer: A clinical assessment. J Natl Cancer Inst 77: 869-875, 1986.

10. Brunner KT, Mauel J, Cerottini JC and Chapuis B: Quantitative assay of the lytic action of immune lymphoid cells on 51-Cr-labelled allogeneic target cells in vitro; inhibition by isoantibody and by drugs. Immunology 14: 181-196, 1968.

11. Pross HF, Baines MG, Rubin P, Shragge P and Patterson MS: Spontaneous human lymphocyte-mediated cytotoxicity against tumor target cells. IX. The quantitation of natural killer cell activity. J Clin Immunol 1: 51-63, 1981.

12. Kim JC, Choi J, Lee SJ, Lee YA, Jeon YM, Kang YW and Lee JK: Evaluation of cytolytic activity and phenotypic changes of circulating blood immune cells in patients with colorectal cancer by a simple preparation of peripheral blood mononuclear cells. J Korean Surg Soc 85: 230-235, 2013.

13. White D, Jones DB, Cooke T and Kirkham N: Natural killer (NK) activity in peripheral blood lymphocytes of patients with benign and malignant breast disease. Br J Cancer 46: 611-616, 1982.

14. Hartung T and Daston G: Are in vitro tests suitable for regulatory use? Toxicol Sci 111: 233-237, 2009.

15. Smith C, Jalbert E, de Almeida V, Canniff J, Lenz LL, Mussi-Pinhata MM, Cohen RA, Yu Q, Amaral FR, Pinto J, et al: Altered natural killer cell function in HIV-exposed uninfected infants. Front Immunol 8: 470, 2017

16. Mhatre S, Madkaikar M, Ghosh K, Desai M, Pujari V and Gupta M: Rapid flow cytometry based cytotoxicity assay for evaluation of NK cell function. Indian J Exp Biol 52: 983-988, 2014.

17. Cho D, Shook DR, Shimasaki N, Chang YH, Fujisaki H and Campana D: Cytotoxicity of activated natural killer cells against pediatric solid tumors. Clin Cancer Res 16: 3901-3909, 2010.

18. Grimm EA, Mazumder A, Zhang HZ and Rosenberg SA Lymphokine-activated killer cell phenomenon. Lysis of natural killer-resistant fresh solid tumor cells by interleukin 2-activated autologous human peripheral blood lymphocytes. J Exp Med 155: 1823-1841, 1982

19. Tartter PI, Steinberg B, Barron DM and Martinelli G: The prognostic significance of natural killer cytotoxicity in patients with colorectal cancer. Arch Surg 122: 1264-1268, 1987.

20. Lin CC, Kuo YC, Huang WC and Lin CY: Natural killer cell activity in lung cancer patients. Chest 92: 1022-1024, 1987.

21. Hanna N and Schneider M: Enhancement of tumor metastasis and suppression of natural killer cell activity by beta-estradio treatment. J Immunol 130: 974-980, 1983.

22. Espi A, Arenas J, Garcia-Granero E, Marti E and Lledó S: Relationship of curative surgery on natural killer cell activity in colorectal cancer. Dis Colon Rectum 39: 429-434, 1996.

23. Beano A, Signorino E, Evangelista A, Brusa D, Mistrangelo M, Polimeni MA, Spadi R, Donadio M, Ciuffreda L and Matera L: Correlation between NK function and response to trastuzumab in metastatic breast cancer patients. J Transl Med 6: 25, 2008.

24. Pollock RE, Lotzová E and Stanford SD: Mechanism of surgical stress impairment of human perioperative natural killer cel cytotoxicity. Arch Surg 126: 338-342, 1991.

25. Lennard TW, Shenton BK, Borzotta A, Donnelly PK, White M Gerrie LM, Proud G and Taylor RM: The influence of surgical operations on components of the human immune system. Br J Surg 72: 771-776, 1985.

26. Pollock RE, Lotzová E and Stanford SD: Surgical stress impairs natural killer cell programming of tumor for lysis in patients with sarcomas and other solid tumors. Cancer 70: 2192-2202, 1992

27. Greenfeld K, Avraham R, Benish M, Goldfarb Y, Rosenne E, Shapira Y, Rudich T and Ben-Eliyahu S: Immune suppression while awaiting surgery and following it: Dissociations between plasma cytokine levels, their induced production, and NK cell cytotoxicity. Brain Behav Immun 21: 503-513, 2007.

28. Bryant J, Day R, Whiteside TL and Herberman RB: Calculation of lytic units for the expression of cell-mediated cytotoxicity. J Immunol Methods 146: 91-103, 1992.

29. Pollock RE, Zimmerman SO, Fuchshuber P and Lotzová E: Lytic units reconsidered: Pitfalls in calculation and usage. J Clin Lab Anal 4: 274-282, 1990.

30. Bloom ET and Korn EL: Quantification of natural cytotoxicity by human lymphocyte subpopulations isolated by density: Heterogeneity of the effector cells. J Immunol Methods 58: $323-335,1983$
31. Montelli TC, Peracoli MT, Gabarra RC, Soares AM and Kurokawa CS: Familial cancer: Depressed NK-cell cytotoxicity in healthy and cancer affected members. Arq Neuropsiquiatr 59: 6-10, 2001

32. Kim GS, Youn JK, Kim JD and Kim NH: Natural killer cell activity in rheumatoid arthritis measured by a single cell cytotoxicity assay. Yonsei Med J 29: 160-165, 1988.

33. Fernandez NC, Lozier A, Flament C, Ricciardi-Castagnoli P, Bellet D, Suter M, Perricaudet M, Tursz T, Maraskovsky E and Zitvogel L: Dendritic cells directly trigger NK cell functions: Cross-talk relevant in innate anti-tumor immune responses in vivo. Nat Med 5: 405-411, 1999.

34. Zingoni A, Sornasse T, Cocks BG, Tanaka Y, Santoni A and Lanier LL: Cross-talk between activated human NK cells and CD4+ T cells via OX40-OX40 ligand interactions. J Immunol 173: 3716-3724, 2004.

35. Terme M, Chaput N, Combadiere B, Ma A, Ohteki T and Zitvogel L: Regulatory T cells control dendritic cell/NK cell cross-talk in lymph nodes at the steady state by inhibiting CD4+ self-reactive T cells. J Immunol 180: 4679-4686, 2008.

36. Ogawa K, Hirai M, Katsube T, Murayama M, Hamaguchi K, Shimakawa T, Naritake Y, Hosokawa T and Kajiwara T: Suppression of cellular immunity by surgical stress. Surgery 127: 329-336, 2000

37. Na YM, Kim MY, Kim YK, Ha YR and Yoon DS: Exercise therapy effect on natural killer cell cytotoxic activity in stomach cancer patients after curative surgery. Arch Phys Med Rehabil 81: 777-779, 2000.

38. Choi J, Lee SJ, Lee YA, Maeng HG, Lee JK and Kang YW: Reference values for peripheral blood lymphocyte subsets in a healthy korean population. Immune Netw 14: 289-295, 2014.

39. Saito H, Osaki T and Ikeguchi M: Decreased NKG2D expression on NK cells correlates with impaired NK cell function in patients with gastric cancer. Gastric Cancer 15: 27-33, 2012.

40. Lee JC, Lee KM, Kim DW and Heo DS: Elevated TGF-beta1 secretion and down-modulation of NKG2D underlies impaired NK cytotoxicity in cancer patients. J Immunol 172: 7335-7340, 2004.

41. Hilpert J, Grosse-Hovest L, Grünebach F, Buechele C, Nuebling T, Raum T, Steinle A and Salih HR: Comprehensive analysis of NKG2D ligand expression and release in leukemia: Implications for NKG2D-mediated NK cell responses. J Immunol 189: 1360-1371, 2012

42. Spear P, Wu MR, Sentman ML and Sentman CL: NKG2D ligands as therapeutic targets. Cancer Immun 13: 8, 2013

43. Bellone G, Aste-Amezaga M, Trinchieri G and Rodeck U: Regulation of NK cell functions by TGF-beta 1. J Immunol 155: 1066-1073, 1995

44. Sun C, Fu B, Gao Y, Liao X, Sun R, Tian Z and Wei H: TGF- $\beta 1$ down-regulation of NKG2D/DAP10 and 2B4/SAP expression on human NK cells contributes to HBV persistence. PLoS Pathog 8 : e1002594, 2012.

45. Krasagakis K, Thölke D, Farthmann B, Eberle J, Mansmann U and Orfanos CE: Elevated plasma levels of transforming growth factor (TGF)-beta1 and TGF-beta 2 in patients with disseminated malignant melanoma. Br J Cancer 77: 1492-1494, 1998.

46. Ghiringhelli F, Ménard C, Terme M, Flament C, Taieb J, Chaput N, Puig PE, Novault S, Escudier B, Vivier E, et al: CD4+CD25+ regulatory $T$ cells inhibit natural killer cell functions in a transforming growth factor-beta-dependent manner. J Exp Med 202: 1075-1085, 2005.

47. Lima M, Teixeira MA, Queirós ML, Leite M, Santos AH, Justiça B and Orfão A: Immunophenotypic characterization of normal blood CD56+lo versus CD56+hi NK-cell subsets and its impact on the understanding of their tissue distribution and functional properties. Blood Cells Mol Dis 27: 731-743, 2001.

48. Bryceson YT, Fauriat C, Nunes JM, Wood SM, Björkström NK, Long EO and Ljunggren HG: Functional analysis of human NK cells by flow cytometry. Methods Mol Biol 612: 335-352, 2010.

49. Kane KL, Ashton FA, Schmitz JL and Folds JD: Determination of natural killer cell function by flow cytometry. Clin Diagn Lab Immunol 3: 295-300, 1996. 